\title{
ANÁLISE E PRODUÇÃO DE TEXTOS
}

\section{SANTOS, L. W.; RICHE, R. C.; TEIXEIRA, C. S.. ANÁLISE E PRODUÇÃO DE TEXTOS. SÃO PAULO: CONTEXTO, 2012}

\section{ACIR MARIO KARWOSKI* BEATRIZ GAYDECZKA**}

Logo nas primeiras páginas, as autoras dedicam o livro a todos os colegas professores, sempre lutando para melhorar o ensino, dedicatória antecedida por uma linda mensagem do escritor Bartolomeu Campos Queirós: "Texto e leitor ultrapassam a solidão individual para se entrelaçarem pelas interações. (...) Ler é somar-se ao mundo, é iluminar-se com a claridade do já decifrado. Escrever é dividir-se. Cada palavra descortina um horizonte, cada frase anuncia outra estação. E os olhos, tomando as rédeas, abrem caminhos, entre linhas, para as viagens do pensamento." Poderia um livro iniciar melhor?

Um verdadeiro convite para a viagem pelo mundo da leitura, da escuta e escrita de textos e da análise linguística. A perspectiva de gramática adotada no livro é considerá-la "instrumento para reflexão sobre os usos linguísticos, visando não só a ampliar o conhecimento teórico sobre a língua, mas também a ajudar na compreensão dos textos e na melhoria da qualidade das produções textuais dos alunos. " (p. 14)

O livro contém 190 páginas, apresenta boa diagramação, bonita capa, contém ilustrações e muitas bem selecionadas propostas de atividades. Contempla uma grande quantidade de gêneros textuais orais e escritos. Certamente, o professor tem inúmeras e diversificadas sugestões para

\footnotetext{
* Universidade Federal do Triângulo Mineiro (UFTM). Instituto de Educação, Letras, Artes, Ciências Humanas e Sociais - IELACHS. Email: acirmario@letras.uftm.edu.br.

** Universidade Federal do Triângulo Mineiro (UFTM). Instituto de Ciências Tecnológicas e Exatas - ICTE. Email: beatriz.gaydeczka@icte.uftm.edu.br.
} 
implementar em sala de aula, analisar os resultados e criticar as atividades propostas. A obra é um farto e diversificado material para utilização em sala de aula.

Nem todas as atividades podem ser realizadas ipsis litteris. O professor deve considerar o nível dos estudantes. Dentre os principais tópicos discutidos na obra podemos enumerar: práticas de linguagem; ensino de língua portuguesa; texto, coesão e coerência; tipologias e gêneros textuais; a especificidade dos gêneros textuais orais; práticas de leitura de textos orais e escritos; concepções de leitura e formação de leitores; etapas e estratégias de leitura; prática de análise linguística; abordagens no ensino de gramática; produção de textos orais e escritos; propostas de atividades integrando as práticas de linguagem, além de muitas sugestões de atividades para sala de aula.

Não precisa de mais nada! O principal desafio para as autoras é trabalhar as três práticas de linguagem apresentadas nos Parâmetros Curriculares Nacionais (PCN) de Língua Portuguesa de maneira articulada. Segundo as autoras, "não é copiando e repetindo partes do texto lido como resposta às questões de "interpretação" - técnica comumente usada na sala de aula - que se formarão leitores competentes e críticos capazes de ler e produzir textos de qualidade: formamos leitores quando mostramos como os elementos presentes no texto colaboram para a construção de sentido." (p. 23)

As autoras conseguem fazer isso muito bem na obra! Certamente, a principal tarefa da escola é formar leitores e produtores críticos de textos orais e escritos, com conhecimentos linguísticos e textuais suficientes para serem cidadãos, leitores de mundo (p. 25). E quanto à análise linguística, às vezes pouco compreendida e, portanto, sem sempre desenvolvida de forma adequada nas aulas de língua portuguesa, ao mesclar "características dos gêneros textuais e das tipologias, observando como se constituem os textos e que aspectos coesivos se destacam" (p. 37), podemos integrar leitura e produção textual com análise linguística, como pregam os Parâmetros Curriculares Nacionais de Língua Portuguesa. Assim, o texto deixa de ser algo abstrato, cujo único objetivo é servir de avaliação do professor, para passar a manifestar ideias, emoções, desejos e descobertas dos alunos. 
Os estudantes de um modo geral, em escolas públicas ou privadas, demonstram interesse e curiosidade por novas aprendizagens. $\mathrm{O}$ professor mediador utilizará as estratégias para estimular a leitura e constante busca de novos sentidos para os textos. Segundo as autoras, "essa curiosidade, essa busca por construir o sentido, pela compreensão, acompanha-nos diante de qualquer texto, oral ou escrito, e pode ser trabalhada em sala de aula." (p. 48) Esse trabalho pode ser realizado por meio de "projetos de leitura, que podem incluir atividades envolvendo todo o entorno da escola, para melhor integração entre alunos e sua comunidade." (p. 50).

Quanto à prática de análise linguística, as abordagens no ensino de língua portuguesa são três: prescritiva, descritiva e produtiva. Segundo as autoras, "o professor poderá adotar os três tipos de abordagens, priorizando, obviamente, a produtiva. No entanto, na prática, as duas outras, sobretudo a descritiva, têm sido ainda as mais enfatizadas nas aulas de língua materna." Na visão das autoras, análise linguística deve integrar-se com leitura e produção de textos; oportunizar o trabalho de reflexão sobre o uso dos recursos linguísticos a partir da análise de casos particulares identificados em textos; focar-se com ênfase nos efeitos de sentidos associados aos gêneros textuais e, por último, estar associada com as reflexões sobre o uso (habilidade epilinguística) e com a reflexão voltada para a descrição (habilidade metalinguística).

A proposta de trabalho apresentada pelas autoras requer mudança de paradigmas no ensino de língua portuguesa. O professor precisa estudar, pesquisar, planejar e empenhar-se para alcançar resultados satisfatórios no ensino. Motivação, interesse e dedicação dos professores não faltam neste país.

Quanto aos textos selecionados para compor a obra, não há dúvida de que a quantidade e a qualidade contemplam diversos gêneros de textos. Faltam, no entanto, abordagens sobre multimodalidade, letramentos, leitura, escrita e análise linguística das práticas e usos de textos em ambiente digital.

Quanto às autoras, Leonor Werneck Santos é professora da Universidade Federal do Rio de Janeiro (UFRJ), mestre e doutora em língua portuguesa pela mesma instituição; Rosa Cuba Riche é professora da 
Universidade do Estado do Rio de Janeiro (UERJ), mestre em literatura brasileira e doutora em teoria da literatura (UFRJ); e Cláudia Souza Teixeira é professora no Instituto Federal de Educação, Ciência e Tecnologia do Rio de Janeiro (IFRJ), mestre e doutora em língua portuguesa pela UFRJ. Todas as autoras têm vasta experiência em ensino de língua portuguesa e formação de leitores e/ou de professores, e possuem diversas publicações científicas e didáticas.

A obra Análise e produção de textos - pertencente à coleção Linguagem \& Ensino - é outro livro de excelente conteúdo publicado pela Editora Contexto, dirigido aos professores e estudantes dos cursos de Letras e áreas afins. A obra destina-se a orientar e capacitar professores de línguas nas recentes inovações de teorias e práticas linguísticas.

Recebido em: 06/11/12. Aprovado: 13/05/13. 